\title{
Identification of patients with triple antiphospholipid antibody positivity is platform and method independent
}

\author{
Teresa Iwaniec, Marcin P. Kaczor, Magdalena Celińska-Löwenhoff, \\ Stanisław Polański, Jacek Musiał \\ 2nd Department of Medicine, Jagiellonian University Medical College, Kraków, Poland
}

\section{KEY WORDS}

antiphospholipid

antibodies,

antiphospholipid

syndrome,

chemiluminescent

immunoassay,

enzyme-linked

immunosorbent assay,

triple positivity

\section{ABSTRACT}

INTRODUCTION The risk of clinical complications in antiphospholipid syndrome (APS) increases when a patient is positive for all 3 types of antiphospholipid (aPL) antibodies. However, there is a considerable disagreement between various platforms for aCL and anti- $\beta_{2}$-glycoprotein I (anti- $\beta_{2} \mathrm{GPI}$ ) measurement, which leads to discrepancies between these platforms in assessing aPL antibody positivity.

OBJECTIVES The aim of this retrospective cross-sectional study was to assess whether 2 different platforms, the QUANTA Lite ${ }^{\circledR}$ enzyme-linked immunosorbent assay and the QUANTA Flash ${ }^{\circledR}$ chemiluminescent immunoassay, identify the same subjects as triple positive in a group of patients with APS and comorbid autoimmune diseases.

PATIENTS AND METHODS The study included 220 patients with systemic autoimmune diseases ( 74 with primary APS; 47 with secondary APS; and 99 with systemic lupus erythematosus without APS). All patients were tested for IgG and IgM aCL and anti- $\beta_{2} \mathrm{GPI}$ antibodies using both platforms.

RESULTS The agreement between the positive results for individual antibodies obtained using both platforms was not full, ranging from $81.8 \%$ to $90.9 \%$ in a pair-wise comparison. However, the number of patients with triple aPL antibody positivity was similar ( 80 by QUANTA Lite ${ }^{\circledR}$ and 86 by QUANTA Flash ${ }^{\circledR}$ ); the agreement between the 2 platforms for the identification of patients with triple antibody positivity was $95.5 \%$ (Cohen's kappa coefficient $=0.90$ ). This resulted in a similar risk for APS-related clinical complications: an odds ratio of 24.9 for QUANTA Lite ${ }^{\circledR}$ and of 24.7 for QUANTA Flash ${ }^{\circledR}$.

concLusions Our results confirm a strong association between triple aPL antibody positivity and APS and indicate that the identification of patients with triple antibody positivity is platform independent. When aPL antibody profiles are assessed, the agreement between various methods is much higher than that for individual antibodies.

INTRODUCTION The international consensus statement on the classification criteria for definite antiphospholipid syndrome (APS) specifies anticardiolipin (aCL) and anti- $\beta_{2}$-glycoprotein I (anti- $\beta_{2}$ GPI) antibodies of the immunoglobulin (Ig) $\mathrm{G}$ or IgM isotype in a medium or high titer as one of the laboratory criteria. ${ }^{1}$ However, the agreement between various methods for $\mathrm{aCL}$ and anti- $\beta_{2}$ GPI antibody measurement is known to be suboptimal owing to discrepancies in the cutoff value, calibration, and technology. ${ }^{2.5}$ Consequently, the method that is used to assess the antiphospholipid antibody (aPL) status of a patient has a major impact on the consistency in diagnosis across different institutions.

The consensus statement (published in 2006) advises investigators to classify patients with APS into groups based on the number of laboratory criteria present: I) more than 1 laboratory criterion present (any combination); IIa) lupus anticoagulant (LAC) present alone; IIb) aCL antibody present alone; and IIc) anti- $\beta_{2}$ GPI antibody present alone. ${ }^{1}$ Since then, a large number of publications have demonstrated that aPL antibody 
profiling is useful not only as a diagnostic tool but also for assessing thrombotic risk. ${ }^{5,6}$

The risk for the first thrombosis in asymptomatic aPL antibody carriers was strongly associated with a triple positive antibody profile in several independent studies, where triple positivity was defined as a positive result in 3 different aPL antibody assays. ${ }^{7-9}$ Moreover, the cumulative incidence of thromboembolic events during a 10-year follow-up of patients with symptomatic APS was $44.2 \%$ in those with 3 positive aPL antibody results. ${ }^{10}$ Pregnancy failure during conventional therapies was also independently associated with triple aPL antibody positivity. ${ }^{11}$ It has been demonstrated that when initially positive aPL testing was repeated after 12 weeks according to the recommendations of the classification criteria, $98 \%$ of the subjects with triple antibody positivity had their aPL antibody status confirmed, in contrast with only $40 \%$ of single-positive subjects. ${ }^{12}$ These results suggest that triple positivity allows to diagnose APS with high reliability.

Given the importance of the triple positive aPL antibody status, our goal was to assess whether 2 different measurement methods, an enzymelinked immunosorbent assay (ELISA) and a novel microparticle chemiluminescent immunoassay (CIA), identify the same subjects with APS and comorbid autoimmune diseases as triple positive.

PATIENTS AND METHOdS Patients This was a retrospective cross-sectional study including 220 patients. Samples were collected at the Immunological Outpatient Clinic, Department of Internal Medicine, Jagiellonian University Medical College (Kraków, Poland) from patients referred to the clinic with a suspicion of systemic lupus erythematosus (SLE) or APS (or both). Of 220 patients, 74 had the diagnosis of primary APS; 47, of secondary APS; and 99, of SLE without APS. In the group of patients with secondary APS, 46 patients were diagnosed with SLE and 1 with mixed connective tissue disease. Data on the history of venous thrombosis, arterial thrombosis, and obstetric complications were available for all subjects. Thrombotic complications were confirmed in 111 patients (81 episodes of venous thrombosis and 43 episodes of arterial thrombosis), and pregnancy morbidity- in 30 of 97 women ever pregnant. A diagnosis of APS was made on the basis of the updated APS criteria. ' SLE was diagnosed according to the updated criteria of the American College of Rheumatology, whenever at least 4 criteria were fulfilled. ${ }^{13,14}$ The study was approved by a local ethics committee, and informed consent was obtained from all patients according to the Declaration of Helsinki.

Sample preparation Blood samples for the measurement of $\mathrm{aCL}$ and anti- $\beta_{2} \mathrm{GPI}$ antibodies were collected in serum separation tubes and spun for 10 minutes at $3500 \mathrm{rpm}$ at room temperature within 2 hours from sampling. Serum samples were then stored at $-80^{\circ} \mathrm{C}$ until further analysis. For the detection of LAC, blood was drawn in sodium citrate tubes $(3.2 \%$ [0.109 $\mathrm{mol} / \mathrm{l}]$; 1 part sodium citrate to 9 parts venous blood). Platelet-poor plasma was prepared by double centrifugation within 2 hours (first: $10 \mathrm{~min} / 3500 \mathrm{rpm}$ and second: $10 \mathrm{~min} / 14000 \mathrm{rpm}$ ) and stored at $-80^{\circ} \mathrm{C}$ for further analysis.

Measurement of autoantibodies All samples were tested for aCL and anti- $\beta_{2}$ GPI antibodies of IgG and IgM isotypes with QUANTA Flash ${ }^{\circledR}$ CIA and QUANTA Lite ${ }^{\circledR}$ ELISA (Inova Diagnostics Inc., San Diego, California, United States) according to the manufacturer's instructions. The presence of LAC was also tested.

QUANTA Flash ${ }^{\circledR}$ aCL and $\mathrm{a} \beta_{2}$ GPI are semiquantitative immunoassays that are run on the fully automated BIO-FLASH ${ }^{\circledR}$ instrument (Biokit S.A., Barcelona, Spain). Results are expressed in (arbitrary) chemiluminescent units.

QUANTA Lite ${ }^{\circledR}$ aCL and anti- $\beta_{2}$ GPI are standard ELISAs for the semiquantitative determination of aCL and anti- $\beta_{2}$ GPI antibodies. The QUANTA Lite ${ }^{\circledR}$ aCL assays report results in GPL and MPL units, and the QUANTA Lite ${ }^{\circledR} \beta_{2}$ GPI assays - in (arbitrary) standard IgG and IgM units.

For the purposes of this study and in accordance with the international guidelines on $\mathrm{aCL}$ and anti- $\beta_{2}$ GPI antibody testing, only the values above the 99 th percentile of the results obtained from 120 sex- and age-matched reference subjects were defined as positive.

LAC was determined in a 3-step procedure according to the guidelines of the International Society on Thrombosis and Haemostasis. ${ }^{15}$ Diluted Russell's viper venom time (LA1-screen; Siemens, Erlangen, Germany) and a sensitive activated partial thromboplastin time (Diagnostica Stago, Gennevilliers, France) were used as screening tests, and LA2-confirm (Siemens) and Staclot LA (Diagnostica Stago) — as confirmatory tests. A reference value was established using the 99th percentile value obtained in the healthy population. A triple aPL antibody positive profile was defined as positivity for LAC and for aCL and anti- $\beta_{2}$ GPI antibodies of the same isotype by the same method.

Single versus triple antibody positivity Single aPL antibody positivity was defined as positivity for one of the following: LAC, aCL antibody, or anti- $\beta_{2}$ GPI antibody. Triple antibody positivity was defined as a positive result in 3 different aPL antibody assays, namely, LAC and $\mathrm{aCL}$ and anti$-\beta_{2}$ GPI antibody of the same isotype. ${ }^{7,8}$

Statistical analysis A statistical analysis was performed using the Analyse-It Software (Version 4.00.1, Leeds, United Kingdom). The Spearman's correlation and Cohen's kappa coefficient tests were performed to assess the quantitative correlation between unit values and qualitative agreement between portions, and $P$ values of less than 
TABLE 1 Clinical performance and area under the curve values of QUANTA Flash ${ }^{\circledR}$ and QUANTA Lite ${ }^{\circledR}$ assays for the association with antiphospholipid syndrome-related clinical symptoms

\begin{tabular}{|c|c|c|c|c|}
\hline Method & Antibody & $\begin{array}{l}\text { AUC } \\
(95 \% \mathrm{CI})\end{array}$ & $\begin{array}{l}\text { Sensitivity, \% } \\
\text { (95\% CI) }\end{array}$ & $\begin{array}{l}\text { Specificity, \% } \\
\text { (95\% CI) }\end{array}$ \\
\hline \multirow[t]{4}{*}{ QUANTA Flash $^{\circledR}$} & $\mathrm{aCL} \lg \mathrm{G}$ & $0.78(0.72-0.84)$ & $65.3(56.5-73.2)$ & $79.8(70.8-86.5)$ \\
\hline & aCL IgM & $0.81(0.75-0.87)$ & $31.4(23.3-40.5)$ & $92.9(86.0-97.1)$ \\
\hline & anti- $\beta_{2}$ GPI IgG & $0.79(0.73-0.85)$ & $71.1(62.1-79.0)$ & $76.8(67.2-84.7)$ \\
\hline & anti- $\beta_{2}$ GPI IgM & $0.78(0.72-0.84)$ & $46.3(37.2-55.6)$ & $89.9(82.2-95.0)$ \\
\hline \multirow[t]{4}{*}{ QUANTA Lite ${ }^{\circledR}$} & $\mathrm{aCL} \lg \mathrm{G}$ & $0.82(0.76-0.87)$ & $66.1(57.0-74.5)$ & $83.8(75.1-90.5)$ \\
\hline & $\mathrm{aCL} \lg \mathrm{M}$ & $0.79(0.74-0.85)$ & $54.5(45.2-63.6)$ & $89.9(82.4-94.4)$ \\
\hline & anti- $\beta_{2} G P I$ lgG & $0.78(0.72-0.84)$ & $59.5(50.2-68.3)$ & $83.8(75.1-90.5)$ \\
\hline & anti- $\beta_{2} G P I$ IgM & $0.79(0.73-0.85)$ & $49.6(40.4-58.8)$ & $85.9(77.4-92.0)$ \\
\hline
\end{tabular}

Abbreviations: aCL, anticardiolipin antibodies; anti- $\beta_{2} \mathrm{GPI}$, anti- $\beta_{2}$ glycoprotein I antibodies; AUC, area under the curve; $\mathrm{Cl}$, confidence interval; IgG, immunoglobulin G; IgM, immunoglobulin M

TABLE 2 Contingency table showing agreement between QUANTA Lite ${ }^{\circledR}$ and QUANTA Flash ${ }^{\circledR}$ aCL IgM and anti- $\beta_{2} \mathrm{GPI} \lg \mathrm{G}$ assays

\begin{tabular}{|c|c|c|c|c|}
\hline \multirow[t]{2}{*}{ Assays } & & \multicolumn{3}{|c|}{ QUANTA Flash ${ }^{\circledR}$ aCL IgM } \\
\hline & & positive & negative & total \\
\hline \multirow[t]{5}{*}{ QUANTA Lite ${ }^{\circledR}$ aCL IgM } & positive & 139 & 4 & 143 \\
\hline & negative & 36 & 41 & 77 \\
\hline & total & 175 & 45 & 220 \\
\hline & & \multicolumn{3}{|c|}{ QUANTA Flash ${ }^{\circledR}$ anti- $\beta_{2}$ GPI lgG } \\
\hline & & positive & negative & total \\
\hline \multirow[t]{3}{*}{ QUANTA Lite ${ }^{\circledR}$ anti- $\beta_{2}$ GPI lgG } & positive & 107 & 25 & 132 \\
\hline & negative & 4 & 84 & 88 \\
\hline & total & 111 & 109 & 220 \\
\hline
\end{tabular}

Abbreviations: See TABLE 1

0.05 were considered significant. A receiver operating characteristic (ROC) curve analysis was used to assess the diagnostic performance of the different immunoassays, and the odds ratio (OR) was calculated to assess the association between aPL antibodies and thrombotic risk.

RESULTS Clinical performance of individual antibody assays Overall diagnostic efficacy To assess the diagnostic efficacy of the various immunoassays, the ROC curve analysis was performed for APSrelated clinical symptoms (any thromboembolic and obstetric complications). The results are presented in TABLE 1. The area under the ROC curve values ranged from 0.78 to 0.82 . A pair-wise comparison of QUANTA Flash ${ }^{\circledR}$ and QUANTA Lite ${ }^{\circledR}$ ROC curves did not reveal any significant differences for either aCL or anti- $\beta_{2}$ GPI antibodies.

Sensitivity and specificity Sensitivity and specificity of aCL IgM antibodies for detecting APS-related clinical symptoms (thrombosis and obstetric complications) were significantly different between the 2 platforms, with the QUANTA Lite ${ }^{\circledR}$ assay being more sensitive ( $54.5 \%$ vs $31.4 \%$ ) but less specific (89.9\% vs $92.9 \%$ ) than the QUANTA Flash $^{\circledR}$ aCL IgM assay (TABLE 2). On the other hand, the QUANTA Lite ${ }^{\circledR}$ anti- $\beta_{2}$ GPI IgG test was significantly less sensitive (59.5\% vs $71.1 \%$ ) and more specific ( $83.8 \%$ vs $76.8 \%$ ) than its QUANTA Flash ${ }^{\circledR}$ counterpart.

Agreement between QUANTA Lite ${ }^{\circledR}$ and QUANTA Flash ${ }^{\circledR}$ assays The overall agreement between QUANTA Lite ${ }^{\circledR}$ and QUANTA Flash ${ }^{\circledR}$ antibody results was good, ranging from $86.8 \%$ to $90.5 \%$ for IgG assays and from $81.8 \%$ to $90.9 \%$ for IgM assays, with Cohen's kappa coefficients between 0.56 to 0.81 , suggesting a moderate to substantial agreement.

Most discrepant results between the 2 platforms were identified for the aCL IgM and anti$\beta_{2}$ GPI IgG assays (TABLE 2).

Clinical performance of triple antibody positive status Despite significant differences between the clinical performance of individual QUANTA Lite ${ }^{\circledR}$ and QUANTA Flash ${ }^{\circledR}$ assays, when patients were classified as having single, double, and triple positivity, the number of triple-positive patients as detected by the 2 platforms was very similar ( 80 by QUANTA Lite ${ }^{\circledR}$ and 86 by QUANTA Flash $^{\circledR}$ ), while there was a significant discrepancy in the number of single-positive patients ( 40 by QUANTA Lite ${ }^{\circledR}$ and 21 by QUANTA Flash $\left.{ }^{\circledR}\right)$. Altogether, 74 of $80(92.5 \%)$ and 79 of $86(91.9 \%)$ triple-positive patients had APS based on a historical 
TABLE 3 Contingency table showing agreement between triple positivity status as identified by QUANTA Lite ${ }^{\circledR}$ and QUANTA Flash ${ }^{\circledR}$ assays

\begin{tabular}{lllll} 
Assays & \multicolumn{3}{c}{ QUANTA Flash ${ }^{\circledR}$ chemiluminescence assay } \\
QUANTA Lite ${ }^{\circledR}$ enzyme-linked immunosorbent assay & no triple positivity & triple positivity & total \\
no triple positivity & 132 & 8 & 140 \\
\hline triple positivity & 2 & 78 & 80 \\
\hline total & 134 & 86 & 220 \\
\hline
\end{tabular}

diagnosis. When APS-related clinical symptoms were considered instead of the diagnosis of APS (to avoid a diagnostic bias), an odds ratio was 24.9 for QUANTA Lite ${ }^{\circledR}$ and 24.7 for QUANTA Flash ${ }^{\circledR}$ in triple-positive patients.

Comparison of triple antibody positive status according to platforms Almost a perfect agreement was observed between the triple positive antibody status identified by QUANTA Lite ${ }^{\circledR}$ and QUANTA Flash ${ }^{\circledR}$ platforms, with a total agreement of $95.5 \%$ (95\% confidence interval [CI], 91.8\%-97.5\%) and a Cohen's kappa of 0.90 (95\% CI, 0.85-0.96). The results are presented in TABLE 3.

DISCUSSION In this cross-sectional study, we have shown that 2 different platforms, an automated microparticle CIA and a traditional ELISA, identified the same patients as having triple aPL antibody positivity.

Over the last decade, a significant progress has been made in the diagnosis and management of APS. Beside the identification of new and promising aPL antibody specificities (antiphosphatidylserine/prothrombin and anti- $\beta_{2}$ GPI Domain 1 antibodies), ${ }^{16}$ several new concepts have been introduced, such as risk stratification, antibody profiling, and establishment of aPL antibody scores. ${ }^{6,17-20} \mathrm{New}$ technologies and platforms have also emerged with favorable analytical and clinical characteristics. ${ }^{17,21,22}$

One of the most important recent findings is the identification of triple antibody positivity as a strong diagnostic and risk stratification tool. ${ }^{6-12,21,23,24}$ Triple positivity has the potential of becoming an excellent laboratory tool for diagnosing APS and predicting thrombosis, but its usefulness may be hindered by the variable performance of different aPL antibody assays. Discrepancies between methods may lead to identifying different patients as triple positive depending on a platform or assay.

At the level of individual aPL antibodies, specifically for aCL IgM and anti- $\beta_{2}$ GPI IgG, significant differences were identified between the QUANTA Lite ${ }^{\circledR}$ and QUANTA Flash ${ }^{\circledR}$ assays in clinical sensitivity and specificity, together with a high level of disagreement in the classification of patients as antibody positive or negative. However, we have shown that a similar number of triple-positive patients were identified by the 2 methods: 80 with QUANTA Lite ${ }^{\circledR}$ and 86 with QUANTA Flash ${ }^{\circledR}$. In addition, we have confirmed a strong association between triple antibody positivity and APS, regardless of the method. The OR for APS-related symptoms was 24.9 based on QUANTA Lite ${ }^{\circledR}$ results and 24.7 based on QUANTA Flash ${ }^{\circledR}$ results. This value is similar to the OR of 33.3 reported by Pengo et $\mathrm{al}^{6}$ in a large Italian cohort. Moreover, despite the differences between individual assays, we observed a total agreement of $95.5 \%$ for triple positivity between QUANTA Lite ${ }^{\circledR}$ and QUANTA Flash ${ }^{\circledR}$ platforms, demonstrating that the 2 methods identified the same patients as triple-positive. This finding has important implications for the future use of aPL antibody results because it suggests that the agreement between various platforms is better when assessing aPL antibody profiles than when assessing individual antibodies. In conclusion, our results not only confirm that triple aPL positivity has a strong association with APS, but also demonstrate that the identification of patients with triple antibody positivity is platform independent.

Contribution statement TI contributed to the concept and design of the study as well as the analysis and interpretation of the data. MK interpreted the data and conducted statistical analyses. MC-L was responsible for clinical evaluation of the patients. SP conducted the analysis. JM was responsible for critical writing, revising the manuscript for intellectual content, and the final approval of the manuscript.

Acknowledgments We would like to thank Inova Diagnostics for providing all material and equipment necessary to conduct testing for this study. The study was supported by a research grant from the National Science Centre in Poland (No. 2011/03/B/NZ6/01608; to JM).

\section{REFERENCES}

1 Miyakis S, Lockshin MD, Atsumi T, et al. International consensus statement on an update of the classification criteria for definite antiphospholipid syndrome (APS). J Thromb Haemost. 2006; 4: 295-306.

2 Favaloro EJ, Silvestrini R. Assessing the usefulness of anticardiolipin antibody assays: a cautious approach is suggested by high variation and limited consensus in multilaboratory testing. Am J Clin Pathol. 2002; 118: 548-557.

3 Wong R, Favaloro E, Pollock W, et al. A multi-centre evaluation of the intra-assay and inter-assay variation of commercial and in-house anti-cardiolipin antibody assays. Pathology. 2004; 36: 182-192.

4 Reber G, Tincani A, Sanmarco M, et al. Variability of anti-beta2 glycoprotein I antibodies measurement by commercial assays. Thromb Haemost. 2005; 94: 665-672

5 Swadzba J, Iwaniec T, Szczeklik A, Musial J. Revised classification criteria for antiphospholipid syndrome and the thrombotic risk in patients with autoimmune diseases. J Thromb Haemost. 2007; 5: 1883-1889.

6 Pengo V, Biasiolo A, Pegoraro C, et al. Antibody profiles for the diagnosis of antiphospholipid syndrome. Thromb Haemost. 2005; 93: 1147-1152. 
7 Mustonen P, Lehtonen KV, Javela K, Puurunen M. Persistent antiphos pholipid antibody (aPL) in asymptomatic carriers as a risk factor for future thrombotic events: a nationwide prospective study. Lupus. 2014; 23 1468-1476.

8 Pengo V Ruffatti A, Legnani C, et al. Incidence of a first thromboembolic event in asymptomatic carriers of high-risk antiphospholipid antibody profile: a multicenter prospective study. Blood. 2011; 118: 4714-4718.

9 Pengo V, Denas G, Padayattil S, et al. Diagnosis and therapy of antiphospholipid syndrome. Pol Arch Med Wewn. 2015; 125: 672-677.

10 Pengo V, Ruffatti A, Legnani C, et al. Clinical course of high-risk patients diagnosed with antiphospholipid syndrome. J Thromb Haemost. 2010 8: 237-242.

11 Ruffatti A, Calligaro A, Del RT, et al. Risk-based secondary prevention of obstetric antiphospholipid syndrome. Lupus. 2012; 21: 741-743.

12 Pengo V, Ruffatti A, Del RT, et al. Confirmation of initial antiphospholipid antibody positivity depends on the antiphospholipid antibody profile. J Thromb Haemost. 2013; 11: 1527-1531.

13 Tan EM, Cohen AS, Fries JF, et al. The 1982 revised criteria for the classification of systemic lupus erythematosus. Arthritis Rheum. 1982; 25 1271-1277.

14 Hochberg MC. Updating the American College of Rheumatology revised criteria for the classification of systemic lupus erythematosus. Arthritis Rheum. 1997; 40: 1725.

15 Pengo V, Tripodi A, Reber G, et al. Update of the guidelines for lupus anticoagulant detection. Subcommittee on Lupus Anticoagulant/Antiphospholipid Antibody of the Scientific and Standardisation Committee of the International Society on Thrombosis and Haemostasis. J Thromb Haemost. 2009; 7: 1737-1740.

16 Bertolaccini ML, Amengual 0, Andreoli L, et al. 14th International Congress on Antiphospholipid Antibodies Task Force. Report on antiphospholipid syndrome laboratory diagnostics and trends. Autoimmun Rev. 2014 13: 917-930.

17 De Moerloose P, Reber G, Musial J, Arnout J. Analytical and clinical performance of a new, automated assay panel for the diagnosis of antiphospholipid syndrome. J Thromb Haemost. 2010; 8: 1540-1546.

18 Andreoli L, Tincani A. Beyond the "syndrome": antiphospholipid antibodies as risk factors. Arthritis Rheum. 2012; 64: 342-345.

19 Otomo K, Atsumi T, Amengual 0, et al. Efficacy of the antiphospholipid score for the diagnosis of antiphospholipid syndrome and its predictive value for thrombotic events. Arthritis Rheum. 2012; 64: 504-512.

20 Sciascia S, Bertolaccini ML. Thrombotic risk assessment in APS: the Global APS Score (GAPSS). Lupus. 2014; 23: 1286-1287.

21 Chung Y, Kim JE, Lim HS, Kim HK. Clinical performance of anticardio lipin and antiß2 glycoprotein I antibodies using a new automated chemiluminescent assay: superior thrombotic prediction of combined results measured by two different methods. Blood Coagul Fibrinolysis. 2014; 25: 10-15.

22 Meneghel $L$, Ruffatti A, Gavasso $S$, et al. The clinical performance of a chemiluminescent immunoassay in detecting anti-cardiolipin and anti-beta2 glycoprotein I antibodies. A comparison with a homemade ELISA method. Clin Chem Lab Med. 2015; 53: 1083-1089.

23 Forastiero R. Multiple antiphospholipid antibodies positivity and an tiphospholipid syndrome criteria re-evaluation. Lupus. 2014; 23: 1252-1254.

24 Lim W. Thrombotic risk in the antiphospholipid syndrome. Semin Thromb Hemost. 2014; 40: 741-746. 


\title{
Identyfikacja chorych z potrójnie dodatnimi przeciwciałami antyfosfolipidowymi jest niezależna od metody pomiaru i typu analizatora
}

\author{
Teresa Iwaniec, Marcin P. Kaczor, Magdalena Celińska-Löwenhoff, \\ Stanisław Polański, Jacek Musiał \\ Il Katedra Chorób Wewnętrznych, Uniwersytet Jagielloński, Collegium Medicum, Kraków
}

\section{SŁOWA KLUCZOWE}

metoda

chemiluminescencyjna, metoda

immunoenzymatyczna, przeciwciała antyfosfolipidowe, wynik potrójnie dodatni, zespół antyfosfolipidowy
Adres do korespondencji: dr n. med. Teresa Iwaniec, II Katedra Chorób Wewnętrznych, Uniwersytet Jagielloński, Collegium Medicum, ul. Skawińska 8, 31-066 Kraków, tel.: 124305266 , e-mail: teresaiwaniec@poczta.fm Praca wpłynęta: 03.11.2015. Przyjęta do druku: 04.12.2015. Publikacja online: 22.01.2016. Nie zgtoszono sprzeczności interesów.

Pol Arch Med Wewn. 2016; 126 (1-2): $19-24$

Copyright by Medycyna Praktyczna, Kraków 2016

\section{STRESZCZENIE}

WPROWADZENIE Ryzyko powikłań klinicznych w zespole antyfosfolipidowym (antiphospholipid syndrome - APS) zwiększa się, gdy u chorego występują wszystkie trzy rodzaje przeciwciał antyfosfolipidowych (antiphospholipid - aPL). Niemniej jednak brak zgodności między różnymi metodami pomiaru przeciwciał antykardiolipinowych (anticardiolipin - aCL) oraz przeciw $\beta_{2}$-glikoproteinie I (anti- $\beta_{2} \mathrm{GPI}$ ) jest znaczny, co prowadzi do rozbieżności w ocenie dodatnich wyników pomiędzy tymi metodami.

CELE Celem tego retrospektywnego badania przekrojowego było zbadanie czy dwie różne metody pomiarowe: OUANTA Lite ${ }^{\circledR}$ ELISA (metoda immunoenzymatyczna) i QUANTA Flash ${ }^{\circledR}$ CIA (metoda chemiluminescencyjna) pozwalają zidentyfikować tych samych chorych z potrójnie dodatnim wynikiem oznaczania przeciwciał aPL w grupie pacjentów z APS i towarzyszącymi chorobami autoimmunologicznymi. PACJENCI I METODY Do badania włączono 220 osób z ogólnoustrojowymi chorobami autoimmunologicznymi (74 badanych z pierwotnym APS, 47 badanych z wtórnym APS oraz 99 badanych z toczniem rumieniowatym układowym bez APS). U wszystkich pacjentów oznaczono aCL i anti- $\beta_{2} \mathrm{GPI}$ w klasach $\lg \mathrm{G}$ i IgM z wykorzystaniem obu metod pomiarowych.

WYNIKI Zgodność dodatnich wyników dla pojedynczych przeciwciał uzyskanych obiema metodami nie była pełna, wahała się od $81,8 \%$ do 90,9\% w poszczególnych parach. Liczba pacjentów z dodatnimi wynikami dla wszystkich trzech rodzajów przeciwciał aPL była natomiast podobna (80 dla QUANTA Lite ${ }^{\circledR}$ i 86 dla QUANTA Flash ${ }^{\circledR}$ ); zgodność pomiędzy obiema metodami dla rozpoznania chorych z potrójnie dodatnim wynikiem wynosiła 95,5\% (współczynnik kappa Cohena $=0,90$ ). W rezultacie obserwowano zbliżone ryzyko powikłań klinicznych APS - iloraz szans wynosił 24,9 dla QUANTA Lite ${ }^{\circledR}$ i 24,7 dla QUANTA Flash ${ }^{\circledR}$. WNIOSKI Uzyskane wyniki potwierdzają silny związek pomiędzy obecnością potrójnie dodatnich przeciwciał aPL a APS oraz wykazują, że rozpoznanie chorych z potrójnie dodatnimi przeciwciałami nie zależy od metody oznaczenia. W sytuacji, kiedy oceniane są profile aPL, zgodność pomiędzy różnymi metodami jest znacznie większa niż zgodność dla pojedynczych przeciwciał. 